\title{
Relation of biophysical response of coarcted aortic segment to balloon dilatation with development of recoarctation following balloon angioplasty of native coarctation
}

\author{
P S Rao, B Waterman
}

\begin{abstract}
Objective-To evaluate the role of biophysical response of the coarcted segment to balloon dilatation in the causation of aortic recoarctation.

Setting-Tertiary care centre/university hospital.

Design-Retrospective case series.

Methods-Records of 67 consecutive infants and children undergoing balloon angioplasty of native aortic coarctations were examined for an 8.7 year period ending September 1993. At 12 months (median) follow up catheterisation, 15 (25\%) of 59 children developed recoarctation, defined as a gradient $>20 \mathrm{~mm} \mathrm{Hg}$. Stretch (balloon circumference - preballoon coarcted segment circumference/ preballoon coarcted segment circumference), gain (postballoon coarcted segment circumference - preballoon coarcted segment circumference), and recoil (balloon circumference - postballoon coarcted segment circumference) were calculated from measurements obtained from cineangiograms performed before and immediately after balloon dilatation.
\end{abstract}

Results-The stretch in 44 children without recoarctation (2.18 (1.23)) was similar $(p>0.1)$ to that in 15 children with recoarctation $(1.90(0.65))$, implying that similar balloon dilating stretch was applied in both groups. Greater gain $(p<0.05)$ was observed in the group without recoarctation $(8.8(8.0) \mathrm{mm})$ than in the recoarctation group $(5.7(2.7) \mathrm{mm})$ but this was not substantiated in the infant population. However, the recoil was greater $(p<0.001)$ in the group without recoarctation $(5.1(4.3) \mathrm{mm})$ than in the recoarctation group $(2.1(1.1) \mathrm{mm})$; this was also true in the infant group.

Conclusions-Greater recoil in the patients without recoarctation implies preservation of intact elastic tissue in the coarcted segment. In the recoarctation group, with less recoil, the elastic properties may not have been preserved, thereby causing recoarctation. There might be a more severe degree of cystic medial necrosis in the recoarctation group than in the no recoarctation group. This needs confirmation in future studies.

(Heart 1998;79:407-411)

Keywords: aortic coarctation; recoarctation; balloon angioplasty; cystic medial necrosis
Although balloon angioplasty of native aortic coarctation produces gratifying immediate results, recurrence of obstruction has been observed. Factors responsible for this recurrence have been investigated to a limited degree. ${ }^{1-3}$ Demographic, anatomical, haemodynamic, and technical variables that are likely to be involved in restenosis have been examined. The role of elastic properties of the vessel wall (of the coarcted segment) in the genesis of recoarctation has been studied to a limited degree. ${ }^{4}$ We hypothesise that the biophysical response of coarcted aortic segment may be determine recoarctation. In this paper, we examined the quantitative aspects of stretch, gain, and elastic recoil of the coarcted segment in the genesis of recoarctation following balloon angioplasty.

\section{Methods}

STUDY SUBJECTS

During an 8.7 year period ending September 1993, 67 infants and children underwent balloon angioplasty; the immediate, ${ }^{5}$ intermediate term, ${ }^{6}$ and long term ${ }^{7}$ follow up results of these patients have previously been reported. Details of the case material can be found in these publications. ${ }^{3-7}$ In brief, the ages of the patients were from two days to 15 years (median 1.5 years) at the time of balloon angioplasty: 47 were boys and 20 girls; weights ranged between 2.1 to $60 \mathrm{~kg}$ (mean (SD), 15.7 (14.1) $\mathrm{kg}$ ); and $50(75 \%)$ of 67 had associated cardiac defects.

TECHNIQUE OF BALLOON ANGIOPLASTY

The technique of balloon angioplasty is also described in our previous publications. ${ }^{5-9}$ The initial balloon diameter chosen for balloon angioplasty was based on the size of isthmus of the aortic arch and descending aortic diameter at the level of diaphragm; the selected balloon size was an average of these two diameters. If there was no adequate relief of obstructionnamely residual gradient $>20 \mathrm{~mm} \mathrm{Hg}$ and angiographic narrowing - a balloon as large as the descending aortic diameter (at the level of diaphragm) was chosen for additional dilatation.

\section{FOLLOW UP}

Follow up measurements of arm and leg cuff pressures and echo-Doppler studies were done at one, three, six, and 12 months after balloon angioplasty and yearly thereafter. Cardiac catheterisation and cineangiography were per-
Accepted for publication 3 November 1997 
Table 1 Pressure gradients and coarcted segments

\begin{tabular}{llll}
\hline Measurement & $\begin{array}{l}\text { No recoarctation } \\
\text { (group I) }\end{array}$ & $\begin{array}{l}\text { Recoarctation } \\
\text { (group II) }\end{array}$ & p value \\
\hline $\begin{array}{l}\text { Pressure gradient } \dagger(\mathrm{mm} \mathrm{Hg}) \\
\begin{array}{l}\text { Before angioplasty } \\
\text { After angioplasty }\end{array}\end{array}$ & $\begin{array}{l}4(17) \\
\text { Follow up }\end{array}$ & $52(20)$ & $>0.10$ \\
Coarcted segment diameter $(\mathrm{mm})$ & $9(8)$ & $10(9)$ & $>0.10$ \\
Before angioplasty & & $38(10)$ & $<0.001$ \\
$\begin{array}{l}\text { After angioplasty } \\
\text { Follow up }\end{array}$ & $4.1(2.0)$ & $2.4(0.6)$ & $<0.001$ \\
\hline
\end{tabular}

Values are mean (SD).

†Peak to peak systolic pressure gradients across aortic coarctation recorded during cardiac catheterisation.
STATISTICAL METHODS

The data are expressed as mean (SD) for normally distributed values. Comparison of preand post-balloon angioplasty values were made by paired sample $t$ test, and comparisons between groups made by independent sample $t$ test. Categorical variables were compared using $\chi^{2}$ or Fisher's exact tests. Multiple linear regression was used to assess the relation between the independent main and interactive effects of stretch and recoarctation status and outcomes of gain and recoil. Two tailed significance was set at $\mathrm{p}<0.05$, Bonferroni adjusted when multiple comparisons were made.

formed 12 months after angioplasty in an attempt to evaluate for recoarctation and aneurysmal formation.

MEASUREMENTS

The diameter of the coarcted aortic segments was measured at the narrowest part from an enlarged, frozen cineaortographic frame in anteroposterior and lateral views in the majority of cases, and in left anterior oblique and right anterior oblique views in a few cases. Measurements from both views were averaged to obtain a mean diameter, after correction for magnification, comparing with the diameter of the angiographic catheter. The measurements were made from the cineaortographic frames obtained before and immediately after balloon angioplasty without the knowledge of whether there was aortic recoarctation at follow up.

The diameter of the balloon listed by the manufacturer was used. In a previous study ${ }^{10}$ we compared cineradiographic balloon diameters with those given by the manufacturer and found them to be similar (the ratio of the measurements was close to unity) and therefore balloon diameters given by the manufacturer were used in this study.

The circumference of the coarcted segment and balloon was then calculated $(\pi \mathrm{D})$ in a conventional manner.

\section{CALCULATIONS}

Stretch, gain, and recoil were calculated as follows:

Stretch $=$ (balloon circumference - coarcted segment circumference, pre-BA) $\div$ coarcted segment circumference, pre-BA

Gain $=$ (coarcted segment circumference, post-BA - coarcted segment circumference, pre-BA) $\div$ stretch

Recoil $=$ balloon circumference - coarcted segment circumference, post-BA $\div$ stretch where BA is balloon angioplasty.

Calculation of recoil was based on principles outlined by Rensing et $a l^{11}$ for quantitative assessment of elastic recoil of coronary artery stenotic lesions; however, vessel wall internal circumference was used instead of cross sectional area of vessel lumen. Circumference of the balloon and coarcted segments was used instead of diameter or cross sectional area because the elastic elements of the vessel wall are likely to be distributed along the circumference of the vessel wall.

\section{Results}

The peak to peak systolic pressure gradient across the aortic coarctation decreased $(\mathrm{p}<0.001)$ from (mean (SD)) $46(17)$ to 11 (9) $\mathrm{mm} \mathrm{Hg}$, while the coarcted aortic segment diameter increased $(\mathrm{p}<0.001)$ from $3.5(1.8)$ to $7.6(3.1) \mathrm{mm}$ immediately following balloon angioplasty. Follow up catheterisation and angiographic data were available in 59 (88\%) of 67 patients undergoing balloon angioplasty. Follow up catheterisation peak to peak systolic pressure gradient $(n=59) 14$ (11) months after balloon angioplasty revealed a residual gradient of 16 (15) $\mathrm{mm} \mathrm{Hg}$; these gradients continue to be lower $(p<0.001)$ than those before angioplasty, but higher $(p<0.05)$ than those immediately after angioplasty. The angiographically measured coarcted segment in 59 children was 8.1 (3.8) $\mathrm{mm}$ and remained unchanged $(p=0.44)$ from that measured immediately after balloon angioplasty.

Recoarctation, defined as a peak to peak systolic pressure gradient $>20 \mathrm{~mm} \mathrm{Hg}$ with or without angiographic narrowing, ${ }^{1}$ was present in $15(25 \%)$ of the 59 patients. The incidence of recoarctation was higher in neonates (five of six $(83 \%) ; \mathrm{p}<0.001)$ and infants (seven of 18 $(39 \%) ; \mathrm{p}=0.011$ ) than in children (three of 35 $(8 \%))$.

In the group without evidence of recoarctation (group I, 44 children), the gradient across the coarctation decreased from 44 (17) to 10 (9) $\mathrm{mm} \mathrm{Hg}(\mathrm{p}<0.001)$ and the diameter of coarcted aortic segment increased from 4.1 (2.0) to $8.6(3.1) \mathrm{mm}(\mathrm{p}<0.001)$ immediately after angioplasty; these values improved further to $9(8) \mathrm{mm} \mathrm{Hg}(\mathrm{p}=0.292)$ and $9.8(3.0) \mathrm{mm}$ $(\mathrm{p}<0.001)$, respectively, at follow up (table 1$)$.

In the group with recoarctation (group II, 15 children), the coarctation gradient decreased from $52(20)$ to $10(9) \mathrm{mm} \mathrm{Hg}(\mathrm{p}<0.001)$ and diameter of the coarcted aortic segment increased from $2.4(0.6)$ to $5.8(2.0) \mathrm{mm}$ $(\mathrm{p}<0.001)$ immediately after angioplasty. However, on follow up, the gradient (38 (10) $\mathrm{mm} \mathrm{Hg}$ ) and the diameter of the coarcted segment $(4.4(2.6) \mathrm{mm})$ worsened $(\mathrm{p}<0.01)$ and returned toward preangioplasty values (table 1).

STRETCH/GAIN, STRETCH/RECOIL RELATION There was a modest $(r=0.38)$ but significant $(\mathrm{p}<0.01)$ positive linear relation between stretch and magnitude of gain (table 2). The stretch shows a similar positive linear associ- 
Table 2 Relation of stretch with gain and recoil

\begin{tabular}{ccc}
\hline & rvalue & p value \\
\hline Stretch $v$ gain & & \\
All subjects $(\mathrm{n}=59)$ & 0.38 & $<0.01$ \\
No recoarctation $(\mathrm{n}=44)$ & 0.36 & $<0.05$ \\
Recoarctation $(\mathrm{n}=15)$ & 0.40 & $<0.05$ \\
Stretch $v$ recoil & & \\
All subjects $(\mathrm{n}=59)$ & 0.34 & $<0.01$ \\
No recoarctation $(\mathrm{n}=44)$ & 0.31 & $<0.05$ \\
Recoarctation $(\mathrm{n}=15)$ & 0.66 & $<0.01$ \\
\hline
\end{tabular}

ation with the degree of recoil $(r=0.34$; $\mathrm{p}<0.01$ ) (table 2. The associations were present and similar in both recoarcted and non-recoarcted patients (table 2).

STRETCH

Balloon inflation stretches the coarcted segment. The stretch is the difference between balloon circumference and circumference of the preangioplasty coarcted segment, normalised to the circumference of preangioplasty coarcted segment. In the group without restenosis the stretch was 2.18 (1.23), while in restenosis group it was 1.90 (0.65); these values did not differ significantly $(p>0.1$; table 3).

GAIN

The gain is the difference between the circumference of the coarcted segment pre- and postangioplasty, and represents the increment in the circumference of the coarcted segment after balloon dilatation. This was normalised to the extent of stretch. In group I without recoarctation, the normalized gain was 8.8 (8.0), significantly higher $(p<0.05)$ than in group II with recoarctation (5.7(2.7); fig 1A).

RECOIL

After stretching the coarcted segment with a given sized balloon, the coarcted segment regresses to a smaller size, the extent of which depends upon the elastic properties of the segment and is assessed by subtracting the circumference of the postangioplasty coarcted segment from the balloon circumference. This was also normalised to the degree of stretch. Elastic recoil was $5.1(4.3) \mathrm{mm}$ in group I without recoarctation, significantly greater $(\mathrm{p}<0.001)$ than the $2.1 \quad(1.1) \mathrm{mm}$ recoil observed in group II with recoarctation (fig 1A).

INFLUENCE OF AGE

Although differences in gain and recoil between the two groups are shown in this study, the group without recoarctation was older $(\mathrm{p}<0.001)$ than the recoarctation group $(64.3$ (53.4) months $v 16.8$ (31.1) months, table 3). It is possible that the age (and weight) of the patients alone may account for the differences observed. Therefore, we examined the data of the subgroup of neonates and infants $\leqslant 12$ months from among the study subjects. There were 12 infants in the recoarctation group and 12 infants in the no recoarctation group. The ages and weights were similar $(p>0.1)$ in both groups (table 4 ). The stretch remained similar
( $p>0.1$ ), but the gain normalised to stretch (fig 1B) was similar $(p>0.1)$ in the infant groups, suggesting that differences in gain observed for the entire study subjects may be related to differences in ages or sizes of the patients. However, the normalised recoil continued to be greater $(p<0.05)$ in the group without recoarctation than in the group with recoarctation, at $4.1(2.0) v 2.3(0.9) \mathrm{mm}$ (fig $1 \mathrm{~B})$. Thus the data on the recoil of the coarcted segment in the infants are similar to those of the entire group, and the age and size of the patients do not seem to explain the observed differences in recoil.

\section{Discussion}

We have previously studied the causes of recoarctation following balloon angioplasty of native aortic coarctation ${ }^{13} ; 30$ demographic, anatomical, physiological, and technical variables were examined by logistic regression analysis. These studies identified four risk factors for development recoarctation: (1) age at angioplasty, (2) size of isthmus of the aortic arch, (3) diameter of the coarcted aortic segment before angioplasty, and (4) diameter of the coarcted segment after angioplasty. The younger the child and the smaller the size of the aortic isthmus and coarcted segment (both before and after angioplasty), the greater the probability of recoarctation. ${ }^{3}$ Although Beekman and associates ${ }^{2}$ observed a higher rate of recurrence of coarctation in patients with preangioplasty peak to peak coarctation gradients $\geqslant 50 \mathrm{~mm} \mathrm{Hg}$ than those with gradients $<50 \mathrm{~mm} \mathrm{Hg}$, our data ${ }^{13}$ did not confirm this observation. Neither study examined the biophysical response of the vessel wall to balloon dilatation, a phenomenon that may provide some clues about the origin of restenosis.

Ino et al examined the stretch-recoil-gain relation in 21 patients who underwent balloon angioplasty (14 native and seven postsurgical recoarctation). ${ }^{4}$ They found larger immediate gain and stretch in patients with recoarctation than in those without and concluded that larger gain and stretch were predictors of restenosis. However, they combined the native and postsurgical coarctations, even though there could be a different type of stretch-recoil-gain relation because of scar tissue in recoarctations. In addition they normalised the stretch to the balloon size rather than to the size of the coarcted segment. They also normalised recoil to balloon size instead of to the extent of stretch, but the gain was normalised to coarcted segment before angioplasty. While it is not clear what method is best for calculating these variables, their method is certainly different from ours. In our study, stretch was normalised to the size of the coarcted segment and this indicates how many times the coarcted segment size was stretched compared with its original size was. Since the recoil and gain have a linear or curvilinear relation to the extent of stretch (in both studies) it would seem reasonable for both gain and recoil to be normalised to stretch.

The aortic wall-including the coarcted segment-histologically consists of adventitia, 
Table 3 Comparison of biophysical response of coarcted segment to stretch in all study subjects

\begin{tabular}{llll}
\hline Measurement & $\begin{array}{l}\text { No recoarctation (group I) } \\
(n=44)\end{array}$ & $\begin{array}{l}\text { Recoarctation (group II) } \\
(n=15)\end{array}$ & $p$ value \\
\hline Age (months) & $64.3(53.4)$ & $16.8(31.1)$ & $<0.001$ \\
Weight (kg) & $20.6(14.8)$ & $7.6(6.4)$ & $<0.001$ \\
Stretch & $2.18(1.23)$ & $1.90(0.65)$ & $>0.1$ \\
Gain/stretch $^{\star}$ & $8.8(8.0)$ & $5.7(2.7)$ & $<0.05$ \\
Recoil/stretch & $5.1(4.3)$ & $2.1(1.1)$ & $<0.001$ \\
\hline
\end{tabular}

Values are mean (SD)

${ }^{\star} \mathrm{mm}$ per unit of stretch.
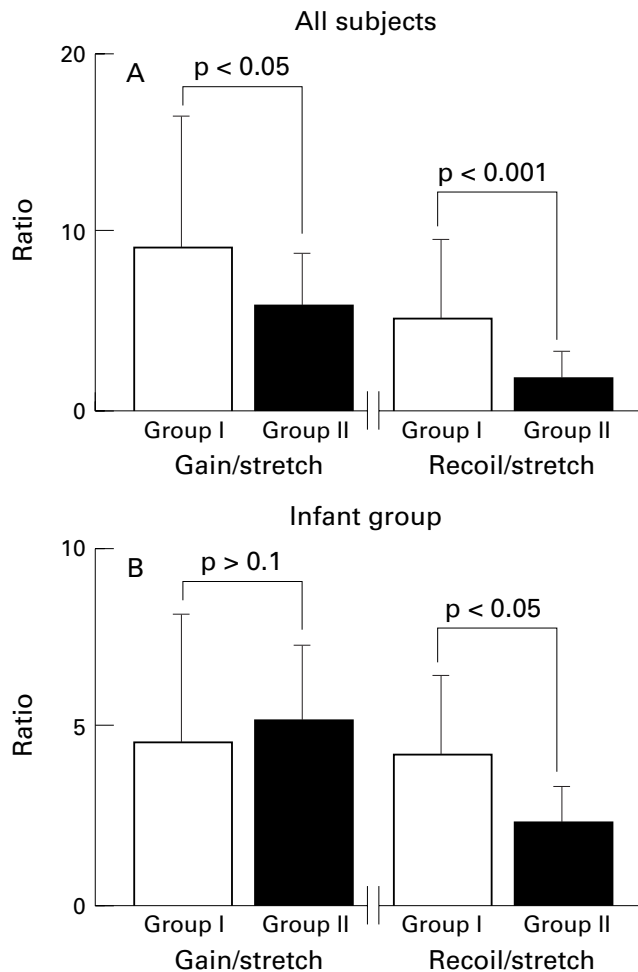

Figure 1 Bar graph showing higher $(p<0.001)$ gain and recoil in the group of subjects without recoarctation (group I) than in those with recoarctation (group II) when the data on all subjects was analysed. When the infant group ( $\leqslant 12$ months) was examined, the gain was similar in both group but the recoil was higher in group I than in group II, thus suggesting that the recoil differences can not be explained by differences in age and weight. Error bars $=S D$

Table 4 Biophysical response of coarcted segment in neonates and infants $\leqslant 12$ months

\begin{tabular}{llll}
\hline Measurement & $\begin{array}{l}\text { No recoarctation } \\
\text { (group I) }(n= \\
\text { 12) }\end{array}$ & $\begin{array}{l}\text { Recoarctation } \\
\text { (group II) }(n=\end{array}$ & 12) \\
\hline Age (months) & $4.5(3.4)$ & $3.0(3.4)$ & $>0.1$ \\
Weight (kg) & $5.6(1.5)$ & $4.8(2.2)$ & $>0.1$ \\
Stretch & $1.96(1.0)$ & $1.85(0.56)$ & $>0.1$ \\
Gain/stretch & $4.6(2.1)$ & $5.1(2.1)$ & $>0.1$ \\
Recoil/ & $4.1(2.0)$ & $2.3(0.9)$ & $<0.05$ \\
$\quad$ stretch $^{\star}$ & & & \\
\hline
\end{tabular}

Values are mean $(\mathrm{SD})$

$\star^{\star}$ mm per unit of stretch.

media, and intima. It is composed of four types of tissue; namely, endothelial lining, elastin fibres, collagen fibres, and smooth muscle. Elastin fibres are mainly concentrated just outside endothelial lining to form a layer of elastic lamina, although they are also found scattered throughout the media and adventitia. These fibres confer elasticity to the aortic wall which is modulated by collagen fibres and perhaps, to some extent, by the smooth muscle. ${ }^{12}$

The dilating stretch that we applied to the coarctated aortic segments is similar in both groups. It is surprising that this is the case considering the fact that the choice of the balloon used for angioplasty was not related to size of the coarcted segment but rather to the sizes of the aortic isthmus and descending aorta at the level of diaphragm. ${ }^{8}$ In the face of nearly equal stretch in both groups, it is unlikely that the magnitude of stretch is responsible for recoarctation. We therefore assume that the response of vessel wall (of the coarcted segment) to the applied stretch is the likely culprit. For the entire group, the gain is greater in the group without recoarctation than in the group with recoarctation; this is not true in the infant group, suggesting that the gain difference may be an artefact produced by differing ages and weights between groups.

It is intriguing that the group without recoarctation shows a greater recoil than the group with recoarctation. We postulate that the group without recoarctation has intact arterial wall elastic properties and thus a "healthier wall," resulting in physical growth commensurate with growth of the remaining aorta. On the other hand, the recoarctation group with less recoil may have an arterial wall that is devoid of elastic properties, which may in turn result in less than optimal growth of the coarcted segment.

Histopathological studies of excised coarcted aortic segments ${ }^{13-15}$ showed abnormalities in the elastic tissue described as cystic medial necrosis ${ }^{14}$ and defined as depletion and disarray of elastic tissue. Variable degrees of elastic tissue abnormality were observed. In some studies, changes typical of cystic medial necrosis were present in some specimens whereas others showed an organised and layered arrangement of elastic fibres. ${ }^{15}$ Other studies showed cystic medial necrosis in all specimens studied, but when the severity was graded, severe changes were present in two thirds of the specimens. ${ }^{14}$ It seems likely that the magnitude of elastic tissue deficiency ${ }^{13}{ }^{14}$ is responsible for differences in recoil response of coarcted segment in our patients. In the group without recoarctation, the elastic elements may be "more intact," promoting adequate recoil response to balloon dilatation and appropriate growth response (secondary to normalised flow $^{16}$ ) during follow up. Conversely, in the group of patients with recoarctation, the elastic elements may be "more deficient," thus fostering less recoil response to balloon dilating stretch.

While we were able to document differences in recoil response to dilatation between the two groups in this study, postulated differences in elastic tissue distribution are speculative. There is a need for further histological studies-or, when such technology develops, the capacity to discern quantitative differences in vessel wall elastic tissue, along with studies by intravascular ultrasound or magnetic resonance imaging. 
We acknowledge and thank Drs O Galal, M K Mardini, L Solymar, M K Thapar, and A D Wilson for their contribution to the clinical material presented in manuscript.

1 Rao, PS, Thapar MK, Kutayli F, et al. Causes of recoarctation after balloon angioplasty of unoperated aortic coarctation after balloon angioplasty of unoperate
tion. $\mathcal{F}$ Am Coll Cardiol 1989;13:109-15.

2 Beekman RH, Rocchini AP, Dick M, et al. Percutaneous Beekman RH, Rocchini AP, Dick $M$, et al. Percutaneous
balloon angioplasty for native coarctation of the aorta. $\mathcal{f}$ Am Coll Cardiol 1987; 10:1078-84

3 Rao PS, Koscik R. Validation of risk factors in predicting recoarctation following initially successful balloon angioplasty for native aortic coarctation. Am Heart $\mathcal{F}$ 1995;130 $116-21$.

4 Ino $\mathrm{T}$, Ohkubo $\mathrm{M}$, Akimoto $\mathrm{K}$, et al. Angiographic assessment of the stretch-recoil-gain relation after balloon coarctation angioplasty and its relation to late restenosis. fpn Circ f 1996;60:102-7.

5 Rao PS. Transcatheter treatment of pulmonic stenosis and coarctation of the aorta: experience with percutaneous balloon dilatation. Br Heart $\mathcal{F}$ 1986;56:250-8.

6 Rao PS, Najiar HN, Mardini MK, et al. Balloon angioplasty for coarctation of the aorta: immediate and long-term for coarctation of the aorta: immedian
results. Am Heart f 1988;115:657-65.

results. Am Heart f 1988;115:657-65.
7 Rao PS, Galal O, Smith PA, et al. Five-to-nine year follow-up results of balloon angioplasty of native aortic follow-up results of balloon angioplasty of native aortic 27:462-70.
8 Rao PS. Technique of balloon valvuloplasty/angioplasty. In: Rao PS, ed; Transcatheter therapy in pediatric cardiology. New York: Wiley-Liss, 1993:29-44.

9 Rao PS. Balloon angioplasty of native coarctation [letter]. $\mathcal{F}$ Am Coll Cardiol 1992;20:756-7.

10 Rao PS. Influence of balloon size on short term and long term results of balloon pulmonary valvuloplasty. Texas Heart Institute f 1987;14:57-61.

11 Rensing BJ, Hermans WRM, Beatt KJ, et al. Quantitative angiographic assessment of elastic recoil after percutaneous transluminal coronary angioplasty. Am $\mathcal{f}$ Cardiol 1990;66: 1039-44.

12 Burton AC. Physiology and biophysics of the circulation. Chicago: Year Book Medical Publishers, 1965:77-83.

13 Balis JV, Chan AS, Conen PE. Morphogenesis of human coarctation. Exp Mol Pathol 1967;6:25-32.

14 Isner JM, Donaldson RF, Fulton D, et al. Cystic medial necrosis in coarctation of the aorta: a potential factor contributing to adverse consequences observed after percutaneous balloon angioplasty of coarctation sites. Circulation 1987;75:689-95.

15 Ho SY, Somerville J, Yip WCL, et al. Transluminal balloon dilation of resected coarcted segments of thoracic aorta: histological study and clinical implications. Int $\mathcal{f}$ Cardiol 1988;19:99-105.

16 Rao PS, Carey P. Remodeling of the aorta after successful balloon coarctation angioplasty. F Am Coll Cardiol 1989;14: $1312-17$ 